\title{
PRAKSIS INTERNALISASI KARAKTER KEMANDIRIAN DI PONDOK PESANTREN YATIM PIATU ZUHRIYAH YOGYAKARTA
}

\author{
Husna Nashihin \\ STAINU Temanggung, Jawa Tengah, Indonesia \\ e-mail: aufahusna.lecture2017@gmail.com
}

\begin{abstract}
This article is a field research that uses the phenomenology approach. Data analysis used in tihis article is qualitative analysis. Zuhriyah Islamic Boarding School is an orphanage-specific boarding school. The internalization of independence character for santri is one of the main goals. This research has the following backgrounds; First, there is still a moral decadence in society today. Second, it is necessary to develop character education using habituation methods based on activities. Third, Zuhriyah Islamic Boarding School has implemented character habituation based on the management of pesantren activities. Fourth, the Zuhriyah Islamic Boarding School is an orphanagespecific boarding school, so there is a demand for santri to be more independent. Fifth, the character of independence becomes the main character instilled in this pesantren. Sixth, there is no research on the habituation of the character of independence in the Zuhriyah Islamic Boarding School. Furthermore, there are three urgent things to study, namely; first, the concept of character education at Zuhriyah Islamic Boarding School. Second, the basic of the internalization of the character of the santri in Zuhriyah Islamic Boarding School. Third, the habituation of the character of the independence of the santri at the Zuhriyah Islamic Boarding School. The concept of character education in the pesantren is in line with the theoretical conception of character education. There are seven activities in Zuhriyah Islamic Boarding School, namely; formal education and yellow book teaching, recitation and routine mujahadah, incidental activities, donations, cooking and cathering for serving food, management of kyai's houses, and cleanliness of the boarding. Habituation of the character of independence is carried out by managing all this seven pesantren activities independently.
\end{abstract}

Keywords: Character Habituation; Independence of Santri; Zuhriyah Islamic Boarding School

Abstrak: Artikel ini merupakan penelitan lapangan yang menggunakan pendekatan Fenomenologi. Analisis data yang digunakan adalah analisis kualitatif. Pondok Pesantren Zuhriyah merupakan pesantren khusus yatim piatu yang menjadikan internalisasi karakter kemandirian santri sebagai salah satu tujuan utama. Penelitian ini memiliki latar belakang sebagai berikut; pertama, masih terjadinya dekandensi moral di tengah masyarakat saat ini. Kedua, perlu adanya pengembangan pendidikan karakter menggunakan metode habituasi dengan berbasis pada kegiatan. Ketiga, Pondok Pesantren Zuhriyah sudah melaksanakan habituasi karakter berbasis pengelolaan kegiatan pesantren. Keempat, Pondok Pesantren Zuhriyah merupakan pesantren khusus yatim piatu, sehingga ada tuntutan lebih dikedepankannya kemandirian santri. Kelima, karakter kemandirian menjadi karakter utama yang ditanamkan di pesantren ini. Keenam, belum adanya penelitian mengenai habituasi karakter kemandirian di Pondok Pesantren Zuhriyah. Selanjutnya ada tiga hal yang urgen untuk dikaji, yaitu; pertama, konsep pendidikan karakter di Pondok Pesantren Zuhriyah. Kedua, basis internalisasi karakter santri di Pondok Pesantren Zuhriyah. Ketiga, habituasi karakter kemandirian santri di Pondok Pesantren Zuhriyah. Konsep pendidikan karakter dipesantren ini sudah sesuai dengan konsepsi teoritis pendidikan

\footnotetext{
J-PAI: Jurnal Pendidikan Agama Islam Vol. 5 No. 1 Juli-Desember 2018 
karakter. Kegiatan santri di Pondok Pesantren Zuhriyah ada tujuh, yaitu; pendidikan formal dan pengajaran kitab kuning, pengajian dan mujahadah rutin, kegiatan insidental, donatur pondok pesantren, konsumsi pondok pesantren, pengelolaan rumah kyai, dan kebersihan pondok pesantren. Habituasi karakter kemandirian dilakukan dengan pengelolaan semua kegiatan pesantren secara mandiri.

Kata Kunci: Habituasi Karakter; Kemandirian Santri; Pondok Pesantren Zuhriyah

\section{PENDAHULUAN}

Realitas menunjukan bahwa dekandensi moral, menjangkitnya ketidakadilan, mahalnya rasa solidaritas, dan lain sebagainya telah melanda masyarakat Indonesia dewasa ini (Doni Koesoema A, 2010, p. 4). Nilai karakter menjadi sangat urgen untuk diinternalisasikan kepada masyarakat Indonesia saat ini di tengah carut marutnya aspek moral yang semakin parah. Agaknya realitas ini cukup menjadi jawaban atas pertanyaan mendasar, ada apa dengan pendidikan di Indonesia saat ini sehingga belum bisa menghantarkan masyarakat yang dididik menjadi pribadi manusia yang lebih baik. Maka tidak heran jika pemerintah berupaya menjadikan karakter sebagai tujuan utama dalam kurikulum yang berlaku saat ini.

Pendidikan menjadi pondasi utama dalam pembentukan karakter bangsa. Namun demikian, tidak bisa dipungkiri pendidikan karakter yang sudah dikembangkan sampai saat ini masih sangat verbalistis. Hal ini juga dikuatkan oleh Dirjen Kelembagaan Agama Islam Departemen Agama yang memaparkan bahwa ukuran keberhasilan pendidikan agama juga masih formalistas (verbalistis). (Abdul Majid dan Dian Andayani, 2005, p. IV).

Arus modernisasi dan globalisasi tidak bisa dipungkiri juga membawa dampak negatif yang sangat terasa, meskipun juga banyak memberikan dampak positif bagi masyarakat. Paling tidak arus ini telah menghantarkan orang tua sebagai pelaku pendidikan utama tergerus dalam kesibukan. Hal ini berimplikasi pada kurangnya perhatian orang tua terhadap perkembangan karakter anak yang sangat dipengaruhi oleh media informasi dan teknologi saat ini.Pelajar SD, SMP, dan SMA yang terlibat tawuran di DKI Jakarta mencapai 0,08\% atau sekitar 1.318 siswa dari total 1.647.835 sebagaimana yang disampaikan oleh Pusat Pengendalian Gangguan Sosial DKI Jakarta (Dharma Kesuma, dkk, 2011, p. 2).

Karakter sejatinya merupakan perkara afektif yang dalam penanamannya harus disertai dengan pembiasaan atau habituasi. Banyak upaya pengembangan pendidikan karakter yang sudah dikembangkan oleh berbagai pihak, termasuk salah satunya pengembangan berbasis pesantren. In'am Sulaiman menegaskan bahwa sampai saat ini pesantren telah terbukti mampu mempertahankan eksistensinya serta mampu menyesuaikan dengan tuntutan zaman (In'am Sulaiman, 2010, p. ix).

Menurut In'am Sulaiman ada dua model pendidikan karakter, yaitu substantif dan reflektif. Model substantif merupakan model pendidikan karakter yang substansi materinya terkait langsung dengan suatu nilai, sedangkan model reflektif merupakan model pendidikan karakter melalui pengambilan nilai dari sebuah kegiatan atau budaya (Dharma Kesuma, dkk, 2011, p. 5). Pondok pesantren Zuhriyah merupakan pesantren khusus anak yatim piatu yang banyak menggunakan pendidikan karakter model reflektif, terutama dalam menanamkan karakter kemandirian bagi santrinya. Basis yang digunakan dalam habiatuasi karakter di pesantren ini menggunakan pengelolaan kegiatan pesantren.

Karakter kemandirian menjadi karakter utama yang ditanamkan di pesantren ini mengingat status yatim piatu yang dimiliki semua santri di pesantren ini. Ada banyak nilai karakter menurut standar yang dikeluarkan oleh Kemendiknas; 1) Religius, 2) Jujur, 3) Toleransi, 4) Disiplin, 5) Kerja Keras, 6) Kreatif, 7) Mandiri, 8) Demokratis, 9) Rasa Ingin Tahu, 10) Semangat Kebangsaan, 11) Cinta Tanah Air, 12) Menghargai Prestasi, 13) Bersahabat/Komunikatif, 14) Cinta Damai, 15) Gemar Membaca, 16) Peduli Lingkungan, 17) Peduli Sosial, dan 18) Tanggung Jawab (Kemendiknas, 2011, p. 3). Karakter mandiri sebagaimana poin ketujuh dalam penjelasan Kemendiknas diatas ternyata juga menjadi karakter nasional yang harus ditanamkan. 
Berdasarkan pemaparan diatas, maka ada beberapa alasan yang melatarbelakangi penelitian ini urgen untuk direalisasikan, yaitu; pertama, masih terjadinya dekandensi moral di tengah masyarakat saat ini. Kedua, perlu adanya pengembangan pendidikan karakter menggunakan metode habituasi dengan berbasis pada kegiatan. Ketiga, Pondok Pesantren Zuhriyah sudah melaksanakan habituasi karakter berbasis pengelolaan kegiatan pesantren. Keempat, Pondok Pesantren Zuhriyah merupakan pesantren khusus yatim piatu, sehingga ada tuntutan lebih dikedepankannya kemandirian santri. Kelima, karakter kemandirian menjadi karakter utama yang ditanamkan di pesantren ini. Keenam, belum adanya penelitian mengenai habituasi karakter kemandirian di Pondok Pesantren Zuhriyah.

Berdasarkan latar belakang tersebut, maka ada tiga rumusan masalah yang perlu dikaji secara mendalam, yaitu pertama, konsep pendidikan karakter di Pondok Pesantren Zuhriyah. Kedua, basis internalisasi karakter santri di Pondok Pesantren Zuhriyah. Ketiga, habituasi karakter kemandirian santri di Pondok Pesantren Zuhriyah. Tujuan penelitian ini antara lain, pertama, mengkonstruksi secara teoritis konsep pendidikan karakter di Pondok Pesantren Zuhriyah. Kedua, menganalisis basis internalisasi karakter santri di Pondok Pesantren Zuhriyah. Ketiga, mendekripsikan secara detail pelaksanaan habituasi karakter kemandirian santri di Pondok Pesantren Zuhriyah.

\section{HASIL DAN PEMBAHASAN}

\section{Konsep pendidikan karakter di Pondok Pesantren Zuhriyah}

Guna merekonstruksi konsep pendidikan karakter di Pondok Pesantren Zuhriyah, peneliti melakukan wawancara, observasi, serta dokumentasi kegiatan di Pondok Pesantren Zuhriyah. Berdasarkan wawancara, observasi, serta dokumentasi kegiatan pesantren yang sudah dilaksanakan, ada beberapa relevansi pelaksanaan pendidikan karakter di pesantren ini dengan konsepsi teoritis mengenai pendidikan karakter yang sekaligus menunjukan bahwa pendidikan karakter yang sudah dilaksanakan sebenarnya sudah mengacu pada konsepsi teoritis pendidikan karakter. Relevansi tersebut antara lain terlihat dalam beberapa hal sebagai berikut:

1. Prinsip-Prinsip Pendidikan Karakter

Pelaksanaan internalisasi karakter harus mengacu pada prinsip-prinsip pendidikan karakter yang sudah dirumuskan oleh beberapa pakar pendidikan karakter. Perumusan prinsipprinsip pendidikan karakter antara lembaga yang satu dengan yang lainnya bisa berbeda-beda tergantung teori yang diambil dan kebutuhan lembaga yang melaksanakan pendidikan karakter. Jika mempertimbangkan model internalisasi karakter kemandirian yang sudah dilaksanakan di pesantren ini, maka prinsip-prinsip yang digunakan sesuai dengan pendapat Lickona.

Lickona menegaskan bahwa berjalan dan tidaknya sebuah praksis pendidikan karakter di sebuah lembaga sangat ditentukan oleh pengetahuan dan kemauan pemangku kebijakan di sebuah lembaga untuk melaksanakan prinsip-prinsip pendidikan karakter, antara lain; pertama, menjadikan nilai-nilai inti sebagai poin utama yang dikembangkan, serta menjadikan nilai-nilai kinerja pendukungnya sebagai dasar pelaksanaannya. Kedua, mendefinisikan karakter secara menyeluruh (komprehensif) sehingga karakter yang dikembangkan dapat mencakup aspek pikiran, perasaan, serta perilaku. Ketiga, menggunakan pendekatan yang menyeluruh (komprehensif), sistematis, serta proaktif. Keempat, memberikan ruang kepada peserta didik untuk merealisasikan karakter menjadi sebuah perilaku moral. Kelima, mendesain kurikulum yang bermakna yang mampu mengoptimalkan potensi dan karakter semua peserta didik. Keenam, menumbuhkan motivasi intrinsik peserta didik dalam menginternalisasikan karakter. Ketujuh, menjadikan semua personil sekolah sebagai sebuah komunitas pelaksana karakter. Kedelapan, merangkul masyarakat sekitar sebagai partner dalam melaksanakan pendidikan karakter. Kesembilan, senantiasa melaksanakan evaluasi pendidikan karakter yang sudah dilaksanakan.

Kesembilan prinsip diatas meskipun merupakan prinsip yang diterapkan dalam pendidikan karakter di sekolah formal, akan tetapi semuanya juga masih relevan untuk diterapkan dan dilaksanakan di pesantren ini. Pondok Pesantren Zuhriyah sebagai sebuah lembaga pendidikan sebenarnya sudah memiliki komponen-komponen pendidikan seperti, tujuan, pendidik, peserta didik, kurikulum, dan lingkungan belajar. Hanya saja, memang untuk penggunaan istilah pendidik jika disesuaikan dengan konteks pesantren, maka diganti dengan kyai atau ustadz. Adapun istilah

\footnotetext{
J-PAI: Jurnal Pendidikan Agama Islam 
peserta didik yang diusung oleh Lickona diatas juga harus diganti dengan istilah santri.

Ada dua prinsip yang cukup menarik dan sudah sangat sesuai dengan pelaksanaan internalisasi yang dilaksanakan pesantren ini, yaitu keterlibatan staf, keluarga, dan masyarakat dalam pendidikan karakter. Jika diterapkan dalam dunia pesantren, maka keterlibatan pemimpin, pengelola, keluarga santri, dan masyarakat sekitar pesantren sangat dibutuhkan dalam proses pendidikan karakter.

Pondok Pesantren Zuhriyah secara proaktif selalu melibatkan masyarakat sekitar dan juga wali santri dalam setiap kegiatan, seperti pengajian akbar, mujahadah, bahkan pengajian rutin yang sering juga dihadiri oleh santri dari luar pesantren (santri kalong). Peliabatan pihak luar ini memang sangat berpengaruh terhadap kelancaran proses internalisasi karakter santri, terutama karakter kemandirian yang menjadi tujuan pendidikan karakter utama santri yang mayoritas yatim piatu ini.

2. Pendekatan dalam Pendidikan Karakter

Secara konsepsi teoritis, dalam duniapendidikan sudah lama dikenal istinal pendidikan nilai. Ada kesamaan substansial antara pendidikan katrakter dengan pendidikan nilai, bahkan bisa dibilang perbedaan diantara keduanya hanyalah perbedaan istilahi saja. Pendekatan yang digunakan dalam pendidikan nilai juga tidak jauh berbeda dengan pendidikan karakter. Nurul Zuriah menjelaskan bahwa pendekatan pendidikan nilai menjadi sangat penting guna mecapai tujuan pendidikan nasional yang sudah ditetapkan. Untuk itu, paling tidak ada dua pendekatan utama dalam pendidikan nilai, yaitu pendekatan penyisipan (plug in) dan pendekatan perbaikan (improvement) yang dilaksanakan dengan memaksimalkan isi, proses, dan pengelolaan pendidikan (Nurul Zuriah, 2011, p. 74).

Jika dilihat dengan menggunakan teori dua pendekatan menurut Nurul Zuriah diatas, maka pendekatan yang digunakan Pondok Pesantren Zuhriyah dalam habituasi karakter kemandirian santri ternyata menggunakan pendekatan penyisipan (plug in) dan juga perbaikan (improvement). Artinya, karakter kemandirian yang akan diinternalisasikan kepada santri merupakan nilai yang disisipkan ( plug in) dalam kegiatan pengelolaan kegiatan pesantren secara mandiri yang juga dilaksanakan dengan upaya perbaikan (improvement) kegiatan melalui evaluasi.

Kedua pendekatan utama diatas, kemudian oleh Nurul Zuriah (2011, pp. 75-76) juga dijelaskan secara lebih rinci sebagai berikut:

a. Pendekatan Penanaman Nilai (Inculcation Approach)

Pendekatan penanaman nilai berusaha menjadikan peserta didik mengetahui dan menerima nilai karakter sebagai miliki sendiri serta bersedia bertanggung jawab atas segala keputusan dalam hidup yang telah diambil. Pendekatan ini dilaksanakan dengan melalui tahapan; mengenal berbagai pilihan karakter, menilai pilihan karakter yang diinginkan, menentukan pilihan karakter, dan menerapkan nilai karakter sesuai dengan kesadaran dirinya sendiri. Pendekatan ini dalam pelaksanaannya mengguna berbagai cara atau metode, antara lain; keteladanan, penguatan positif dan negatif, simulasi, serta bermain peran.

b. Pendekatan Perkembangan Moral Kognitif (Cognitive Moral Development Approach)

Pendekatan ini menekankan pada perkembangan pengetahuan moral peserta didik sesuai dengan tingkatannya. Selanjutnya, dalam implementasinya seorang pendidik kemudian mendorong peserta didiknya untuk membuat keputusan atas perbuatan yang akan dilaksanakan sesuai dengan moralnya. Pendekatan ini menuntut pemahaman antara kesesuaian perilaku dengan prinsipprinsip etika dan moral yang berlaku universal. Adapun dalam pelaksanaannya, pendekatan ini dapat menggunakan berbagai cara atau metode, antara lain; melaksanakan diskusi kelompok dengan tema besar mengenai moral, baik tema moral yang faktual maupun yang sebatas bersifat teoritis atau abstrak (hipotetikal).

\section{c. Pendekatan Analisis Nilai (Value Analyzis Approach)}

Pendekatan ini mengedepankan kemampuan berpikir analisis dan rasional peserta didik. Artinya, pendekatan ini berusaha memberikan peluang kepada peserta didik untuk menganalisis suatu masalah moral tertentu serta membuat sintesa antara masalah yang dihadapi dengan nilai karakter tertentu. Selanjutnyaa, dalam implementasinya, pendekatan ini dapat dilaksanakan dengan cara atau metode seperti; diskusi terarah yang menuntut argumentasi, penegasan dasar aargumentasi, penegasan prinsip, analisis terhadap kasus, debat, dan bahkan berupa penelitian.

\footnotetext{
J-PAI: Jurnal Pendidikan Agama Islam

Vol. 5 No. 1 Juli-Desember 2018

Homepage: http://ejournal.uin-malang.ac.id/index.php/jpai/
} 


\title{
d. Pendekatan Klarifikasi Nilai (Value Clarification Approach)
}

Pendekatan ini berusaha menumbuhkan kemampuan peserta didik dalam mengidentifikasi nilai karakter yang terkandung dalam sebuah aktifitas. Selanjutnya, berdasarkan hasil identifikasi karakter tersebut, peserta didik secara jujur diberikan ruang untuk mengkomunikasikan secara jujur kepada orang lain. Masukan yang diberikan tersebut berfungsi sebagai klarifikasi atas karakter yang telah diidentifikasi. Dalam implementasinya, pendekatan ini dapat menggunakan cara atau metode seperti; bermain peran, simulasi, analisis mendalam tentang nilai, aktivitas yang mengembangkan sensitivitas, kegiatan di luar kelas, dan diskusi kelompok.

e. Pendekatan Pembelajaran Berbuat (Action Learning Approach)

Sebenarnya konsep pendekatan ini kurang lebihnya sama dengan konsep pendekatan analisis nilai dan klarifikasi nilai. Pendekatan ini memberikan kesempatan kepada peserta didik untuk merealisasikan nilai karakter ke dalam sebuah perbuatan. Pendekatan ini mendorong peserta didik untuk berinteraksi dengan lingkungan sekitarnya sebagai makhluk sosial. Dalam implementasinya, pendekatan ini dapat dilaksanakan dengan cara atau metode antara lain; kegiatan sekolah berbasis proyek, kegiatan pengabdian masyarakat, serta kegiatan berbasis organisasi.

Berbagai pendekatan pendidikan karakter diatas merupakan pendekatan pendidikan karakteryang juga dilaksanakan di Pondok Pesantren Zuhriyah. Jika mencoba menilik dengan teori pendekatan karakter lain seperti Hersh, ternyata pendekatan di pesantren ini juga sudah sesuai secara teoritis.

Hampir senada dengan Nurul Zuriah, Hersh memaparkan ada enam pendekatan dalam pendidikan karakter yang biasa digunakan dalam praktek pendidikan karakter, yaitu; pendekatan pengembangan rasional, pendekatan pertimbangan nilai moral, pendekatan klarifikasi nilai, pendekatan pengembangan moral kognitif, pendekatan perilaku sosial, dan pendekatan penanaman nilai. Selanjutnya, Elias yang mencoba mensintesiskan berbagai teori mengenai pendekatan pendidikan karakter tersebut, menyimpulkan pendekatan pendidikan karakter menjadi tiga, yaitu; pendekatan kognitif, pendekatan afektif, dan pendekatan perilaku (Maksudin, 2009, pp. 26-28).

Secara lebih luas dan komprehensif, selanjutnya Kirschenbaum memaparkan pendekatan dalam pendidikan karakter menjadi empat, yaitu inculcating value (inkulkasi), modelingvalue and (keteladanan), facilitating value and morality (fasilitasi nilai), skills for value development and moral literacy (pengembangan ketrampilan hidup) (Howard Kirschenbaum, 2000, pp. 31-43). Pendekatan Kirschenbeum ini kemudian lebih dikenal dengan pendekatan komprehensif pendidikan karakter.

Sebagai upaya penjelas atas pendapat Kirschenbaum tersebut, Darmiyati Zuchdi mencoba menjelaskan berbagai macam alasan yang melatarbelakangi hadirnya pendekatan komprehensif tersebut. Menurutnya, berbagai macam pendekatan baru yang telah ada hanya mampu memberikan solusi bagi masalah masalah pendidikan pendidikan secara parsial belaka. Untuk itu, pendekatan komprehensif ini juga bisa dikatakan sebagai pendekatan simpulan (sintesis) atas berbagai macam pendekatan yang telah ada, baik yang tradisional maupun yang kotemporer. Secara substansial, definisi komprehensif yang dimaksud dalam pendekatan ini mencakup empat hal, yaitu isi, metode, hal yang terjadi dalam semua aspek kegiatandi sekolah, serta hal yang terjadi dalam kehidupan masyarakat (Darmiyati Zuchdi, 2010, pp. 113-114).

Berdasarkan hasil analisis konsepsi teoritis dengan konsepsi pendidikan karakter yang dilaksanakan di Pondok Pesantren Zuhriyah, memang harus diakui bahwa secara tertulis, tidak semua konsepsi teoritis berkenaan dengan pendidikan karakter tersebut diatas sudah didokumentasikan secara tertulis dan sistematis. Meskipun demikian, relevansi antara konsepsi teoritis dengan kondisi real yang ada di pesantren ini agaknya mampu menjadi basis konstruksi pendidikan karakter di Pondok Pesantren Zuhriytah secara konseptual.

\section{Basis Internalisasi Karakter Santri di Pondok Pesantren Zuhriyah}

Internalisasi karakter yang dilaksanakan di Pondok Pesantren Zuhriyah berbasis pada kegiatan pengelolaan semua kegiatan santri. Berdasarkan hasil dokumentasi, wawancara, dan observasi, dapat diketahui bahwa kegiatan santri di pesantren ini bisa dikelompokan menjadi 7

\author{
J-PAI: Jurnal Pendidikan Agama Islam \\ Vol. 5 No. 1 Juli-Desember 2018 \\ Homepage: http://ejournal.uin-malang.ac.id/index.php/jpai/
}


kegiatan. Perbedaan yang mencolok dari pengelolaan semua kegiatan jika dibandingkan dengan pesantren lain terletak pada kemandirian santri dalam menyusun detail perencanaan sampai detail pelaksanaan yang bisa dideskripsikan dalam pembahasan berikut ini;

1. Pendidikan Formal dan Pengajaran Kitab Kuning

Ada dua jenis pendidikan yang dilaksanakan oleh santri di pesantren ini, yaitu pendidikan sekolah formal dan pengajaran kitab kuning. Pengajaran kitab kuning dilaksanakan di dalam pesantren sesuai dengan jadwal yang disusun. Adapun kegiatan belajar mengajar secara formal ditempuh oleh santri di luar Pondok Pesantren, yaitu melalui sekolah di sekitar pesantren. Hal yang menarik dalam pelaksanaan pendidikan formal terletak dalam hal pengurusan sekolah formal, santri senior bertanggung jawab juga membimbing dan mengurus santri yang masih kecil, apalagi santri yatim piatu yang masih kelas Taman Kanak-Kanak (TK).

Hal yang cukup menarik yang dilakukan santri senior terhadap santri junior dalam pengurusan sekolah formal adalah antar jemput yang dilakukan santri senior kepada santri yang masih duduk di bangku Taman Kanak-Kanak atau sekolah dasar tingkat awal. Santri senior sambil berangkat ke sekolah biasanya mengantar adik-adik santri yang belum bisa berangkat sekolah secara mandiri. Tanggung jawab antar jemput ini dibagi berdasarkan musyawarah selayaknya sebuah keluarga.

Kegiatan belajar mengajar di Pondok Pesantren Zuhriyah terdiri dari 8 mata pelajaran yang merujuk pada 8 kitab kuning. Kegiatan ini dilaksanakan setelah sholat Isya berjamaah, tepatnya setelah jam makan malam. Ustadz yang bertugas mengampu setiap mata pelajaran sebagian besar berasal dari luar pesantren. Pengelolaan kegiatan yang dilakukan oleh santri dalam kegiatan ini meliputi; pertama, penjadwalan ustadz, mata pelajaran, kelas, dan waktunya. Kedua, melakukan konfirmasi kehadiran dan perizinan ustadz sesuai jadwal yang telah ditentukan. Ketiga, melakukan penggantian ustadz ketika ada yang izin. Keempat, menyiapkan segala macam media pembelajaran yang dibutuhkan. Kelima, menyiapkan ruang pembelajaran.

Kegiatan belajar mengajar di pesantren ini dilaksanakan setelah sholat Isya, kecuali pada hari libur sekolah. Hal ini mengingat semua santri di pesantren ini sebagian besar juga menempuh pendidikan formal di luar pondok mulai dari tingkat taman kanak-kanak sampai sekolah menengah atas bahkan ada juga yang tingkat perguruan tinggi. Selain pada malam hari, kegiatan belajar mengajar juga dilaksanakan sehabis sholat Subuh.

Kelas dalam kegiatan belajar mengajar di Pondok Pesantren Zuhriyah secara umum dibagi menjadi dua, yaitu kelas santriwan dan santriwati. Penanggung jawab kegiatan belajar mengajar santriwan dan santriwati setiap hari melaksanakan tugas yang terdiri dari 5 hal diatas. Selanjutnya, guna mempermudah koordinasi pelaksanaan kegiatan ini, maka ada ketua pada setiap kelas. Berikut ini data mengenai ustadz, mata pelajaran, kelas, dan juga waktu pelaksanaannya.

Tabel 1. Ustadz, Mata Pelajaran, dan Waktu Pelaksanaan

\begin{tabular}{||l||l|l|l||}
\hline \multicolumn{1}{|c||}{ Nama } & Kelas & \multicolumn{1}{c|}{ Mata Pelajaran } & \multicolumn{1}{c|}{ Hari } \\
\hline \hline Ustadz Ismail & 2 & Jurumiyah & Minggu \\
\hline Ustadz Uki Sukiman & 2 & Nahwu Wade' & Senin \\
\hline Ustadz Nurudin & 2 & Ta'lim Mutaalim & Selasa \\
\hline Ustadz Ngardiono & 2 & Hafalan Juz 'amma & Rabu \\
\hline Ustadz Nur Salim & 2 & Lubabul Khadis & Jum'at \\
\hline Ustadz Mustaqim & 2 & Al-Adzkar & Minggu pagi \\
\hline Ustadz Sholeh & 1 & Ilmu Tajwid & Minggu \\
\hline Ustadz Tanto & 1 & Safinatun Najah & Senin \\
\hline Ustadz Syafa' & 1 & 'Aqidatul Awwam & Selasa \\
\hline Ustadz Ngardiono & 1 & Hafalan Juz 'amma & Rabu \\
\hline Ustadz Sholeh & 1 & Ilmu Tajwid & Jum'at \\
\hline Ustadz Mustaqim & 1 & Al-Adzkar & Minggu pagi1 \\
\hline
\end{tabular}


Ada 12 kitab yang diajarkan di pesantren ini. Semua santri setelah lulus dari pesantren ini diharapkan bisa menguasai kitab-kitab tersebut. Kitab-kitab yang diajarkan terdiri dari berbagai bidang, seperti Akidah, Fikih, Tasawuf, Hadist, dan Tafsir Al-Qur'an.

2. Pengajian dan Mujahadah Rutin

Sebagai bagian yang tidak terpisahkan dari masyarakat setempat, Pondok Pesantren Zuhriyah mengadakan kegiatan sebagi kontribusi dalam mendidik masyarakat sekitar. Kegiatan itu berbentuk pengajian dan mujahadah rutin. Pengajian dan mujahadah juga menjadi tanggung jawab Pondok Pesantren Zuhriyah sebagai salah satu pesantren NU di Yogyakarta.

Pengajian akbar bersama warga di Pondok Pesantren Zuhriyah dilaksanakan setiap sebulan sekali tepatnya pada malam Jumat Wage. Pengelolaan pengajian akbar ini sepenuhnya dikelola oleh santri. Santri putri bertugas mempersiapkan konsumsi pengajian bersama warga sekitar, sedangkan santri putra bertugas mempersiapkan segala perlengkapan pengajian yang meliputi tenda, kursi, panggung, dan sound sistem. Semua perlengkapan pengajian sudah dimiliki oleh Pondok Pesantren Zuhriyah, sehingga santri putra tinggal mempersiapkan segala perlengkapan yang dibutuhkan, mulai dari mendirikan tenda, memasang sound sistem, sampai menata meja dan kursi.

Pengaturan acara pengajian biasanya dikelola oleh santri, mulai dari pembawa acara, pembacaan ayat suci al-Qur'an, sambutan, serta pembagian tugas acara yang lain. Adapun untuk penceramah, biasanya Umi Yaya menugaskan kepada Ustadz yang mengajar di Pondok Pesantren Zuhriyah atau mengundang ustadz dari luar pesantren.

Karakter kemandirian santri dibentuk melalui pengelolaan kegiatan secara mandiri oleh santri terkait dengan segala sesuatu yang berhubungan dengan pengajian dan mujahadah rutin. Santri dalam kegiatan ini diposisikan sebagai panitia yang bertanggung jawab atas terlaksananya kegiatan. Kesulitan-kesulitan yang dihadapi oleh santri, secara mandiri diselesaikan oleh santri.

3. Kegiatan Insidental

Kegiatan insidental yang ada di Pondok Pesantren Zuhriyah merupakan kegiatan yang tidak teragendakan secara rutin. Kegiatan tersebut antara lain acara undangan tahlilan, yasinan, muqoddaman, mujahadah, atau undangan pengajian dari luar pesantren. Sifat acara yang tidak terencana, membuat pengelolaan kegiatan insidental ini harus mengedepankan sikap kerja sama. Sebagai contohnya, ketika dalam satu waktu yang bersamaan, ada dua undangan tahlilan ke luar pesantren, maka tentunya harus ada kerja sama dan saling pengertian untuk bisa membagi tugas menghadiri dua acara yang bersamaan tersebut.

Undangan dari pihak luar pesantren yang membutuhkan bantuan santri dalam acara hajatan biasanya dipimpin langsung oleh Umi Yaya atau Ustadz yang ada di Pondok Pesantren Zuhriyah. Meskipun demikian, segala pengelolaan acara ini menjadi tanggung jawab santri yang sudah menjadi pengurus pesantren. Pengelolaan kegiatan tersebut meliputi pengkoordiniran dan pembagian tugas bagi santri.

Pondok pesantren Zuhriyah sebagai bagian yang tidak terpisahkan dari masyarakat memiliki banyak peran strategis. Kegiatan masyarakat sekitar yang membutuhkan bantuan pesantren sangat banyak, seperti pemimpin tahlil, penceramah pengajian, dan pembaca tilawah alQur'an. Segala bantuan yang dibutuhkan masyarakat sekitar ini dikelola secara mandiri oleh santri.

4. Donatur Pondok Pesantren

Biaya operasional Pondok Pesantren Zuhriyah bersumber dari donator, baik tetap maupun tidak tetap. Donatur tersebut berasal dari pemerintah, perusahaan, maupun perorangan. Pengurusan semua donator tersebut dilakukan oleh santri, meskipun terbatas pada santri yang sudah menjadi pegurus yang dikoordinir oleh seksi keuangan dibawah bimbingan Umi Yaya. Pengurusan donator keuangan di Pondok Pesantren Zuhriyah secara mandiri memang sudah menjadi budaya pesantren yang masih berlangsung sampai saat ini. Hal ini memang dimaksudkan untuk membimbing santri secara mandiri mengenal masalah keuangan. Hal ini tentunya sangat bermanfaat untuk bekal hidup santri setelah tidak berada di pesantren lagi.

Santri yang bertanggung jawab berkenaan dengan donatur pesantren tidak hanya bertugas mengambil uang donatur yang sudah ada saja, akan tetapi juga mencari tambahan donatur jika memang dibutuhkan untuk menutupi kebutuhan pesantren. Pencarian ini meskipun masih sangat didampingi pimpinan pesantren dalam relasi donaturnya, akan tetapi semua pekerjaan teknis yang 
berhubungan dengan pembuatan proposal sampai pengadministrasian donatur kesemuanya dikerjakan oleh santri.

\section{Konsumsi Pondok Pesantren}

Salah satu kegiatan yang rutin dilakukan oleh santri adalah belanja bahan makanan dan pengolahannya sampai siap dihidangkan. Dalam kegiatan harian ini, semua santri dijadwal sehingga semua santri memiliki tugas dan kewajibannya sesuai dengan jadwal yang sudah ditentukan. Adapun tugas memasak dibagi menjadi dua, yaitu memasak untuk pihak keluarga Umi Yaya dan memasak untuk semua santri yang ada di pesantren. Untuk kegiatan memasak bagi keluarga Umi Yaya dilakukan oleh santri yang bertugas menjadi "abdi dalem" atau santri yang secara rutin hanya bertugas mengurus keluarga kyai. Setiap hari kucuali hari libur sekolah, santri di Pondok Pesantren Zuhriyah makan sebanyak dua kali, yaitu pagi sebelum berangkat sekolah dan malam hari setelah sholat Isya. Adapun makan siang ketika hari sekolah, diganti dengan uang konsumsi santri sehingga santri bisa membeli makanan di sekolahan mereka.

Penyusunan jadwal piket memasak dilakukan dengan adil, yaitu mempertimbangkan aspek usia dan ketrampilan memasak. Tugas dan kewajiban memasak hanya dilakukan oleh santri putri saja, meskipun dalam sesekali waktu tertentu seperti peringatan Hari Ibu semua kegiatan memasak dilakukan oleh santri putra. Kegiatan memasak dilakukan setelah Ashar ketika semua santri sudah diperkirakan pulang sekolah. Meskipun dikonsumsi sebanyak dua kali dan dua menu makanan yaitu untuk makan malam dan makan pagi, akan tetapi kegiatan memasak hanya dilakukan sekali saja. Hal ini mengingat kegiatan santri yang sangat padat.

6. Pengelolaan Rumah Kyai

Pengelolaan rumah Umi Yaya dilakukan oleh santri yang sudah menjadi “abdi dalem” yang meliputi pengelolaan kebutuhan makan, pakaian sampai kebersihan lingkungan rumah Umi Yaya. Santri yang menjadi "abdi dalem" biasanya adalah santri yang sudah tidak memiliki beban sekolah. Kegiatan ini merupakan kegiatan yang sudah lazim diselenggarakan di semua pesantren. Pondok Pesantren Zuhriyah sampai saat ini masih melestarikan budaya pesantren ini karena untuk melatih kemandirian santri dan untuk menjaga hubungan yang baik antara santri dengan pemimpin pesantren.

Santri senior yang sudah tidak memiliki beban sekolah formal melaksanakan pengelolaan rumah Umi Yaya dengan menyapu dan mengepel lingkungan rumah, selanjutnya memasak, dan sebagian yang lain ada yang mencuci pakaian. Santri laki-laki sebagian ada juga yang mengelola perkebunan Umi Yaya yang berada di dekat rumah. Kegiatan ini sudah menjadi aktifitas rutin yang dilaksanakan di pesantren ini. Hal yang menarik dari pelaksanaan kegiatan ini adalah tidak adanya perintah yang harus dikeluarkan oleh pengelola pesantren, akan tetapi aktifitas pengelolaan rumah Umi Yaya sudah berjalan dengan sendirinya berdasarkan pada kesadaran santri.

Kegiatan mengelola rumah Umi Yaya ini menjadi media yang sangat efektif untuk menanamkan karakter kemandirian pada santri dalam hal urusan rumah tangga. Santri melalui kegiatan ini akan terbiasa mengerjakan urusan rumah tangga seperti membersihkan rumah, mencuci pakaian, sampai urusan mengenai memasak. Tanggung jawab mengenai pengelolaan rumah kyai inilah yang menjadikan santri di pesantren ini memiliki karakter kemandirian yang kuat dalam hal rumah tangga. Kemandirian yang dimiliki oleh santri dalam pengelolaan rumah Umi Yaya sudah mampu menumbuhkan kesadaran atas tanggung jawab santri terhadap kyainya.

7. Kebersihan Pondok Pesantren

Pengelolaan kebersihan di Pondok Pesantren Zuhriyah dilakukan secara terjadwal. Pengaturan jadwal kebersihan dilakukan dengan membagi semua santri sesuai dengan "jadwal istiqomah". Jadwal istiqomah yang digunakan di pesantren ini mengandung arti bahwa setiap kelompok santri sudah memiliki tanggung jawab lokasi yang harus dibersihkan sendiri. Sebagai contohnya, ketika kelompok santri ada yang memiliki jadwal istiqomah membersihkan aula pesantren, maka secara rutin kelompok tersebut bertugas membersihkan aula pesantren. Adapun lokasi pesantren yang harus dibersihkan setiap hari adalah semua lokasi selain kamar santri karena untuk kebersihan kamar santri sudah secara otomatis menjadi tanggung jawab penghuni kamar. 


\section{Habituasi Karakter Kemandirian Santridi Pondok Pesantren Zuhriyah}

Habituasi karakter kemandirian yang dilaksanakan di Pondok Pesantren Zuhriyah berbasis pada pengelolaan kegiatan santri. Selanjutnya, karakter kemandirian yang diinternalisasikan melalui kegiatan tersebut sampai saat ini menjadi tujuan utama yang harus dimiliki santri. Hal ini jika dilihat dari konsepsi pendidikan karakter senada dengan pendapatnya Doni Koesoema.

Doni Koesoema (2010, pp. 90-91) memaparkan bahwa karakter dapat dipandang sebagai sebuah kondisi yang sudah ada dan harus diinternalisasikan dalam diri manusia. Kondisi seperti ini disebut sebagai given. Selain itu, karakter juga bisa dipandang sebagai sesuatu yang sengaja didesain dan diinternalisasikan dalam diri manusia. Kondisi yang demikian ini disebut sebagai willed.

Jika mencoba menilik menggunakan pendapat Doni diatas, maka karakter kemandirian santri yang ada di Pondok Pesantren Zuhriyah sejatinya merupakan given. Atau sesuatau yang sudah ada dan coba diinternalisasikan dalam diri santri. Hal ini tentunya mempertimbangkan kondisi santri di pesantren ini yang mayoritas yatim piatu. Proses initernalisasi karakter kemandirian di pesantren ini menjadi lebih mudah dilaksanakan, karena santri yang mayoritas yatim piatu sudah memiliki kesadaran bahwa kemandirian merupakan sesuatu yang sudah harus melekat pada dirinya.

Secara terminologis, "karakter" berasal dari bahasa yunani "charassein" yang berarti "mengukir" (Hamka Abdul Azis, 2011, p. 43). Terminologi ini munegaskan bahwa "ukiran" yang diposisikan sama dengan karakter memiliki sifat melekat kuat pada benda yang diukir. Abdullah Munir (2010, pp. 2-3) menambahkan bahwa karakter dideskripsikan sebagai sebuah pola yang terdiri dari pikiran, sikap, maupun tindakan yang sangat susah untuk dihilangkan dari diri seseorang. Pendidikan karakter harus dilaksanakan sejalan dengan pandangan pendidikan Islam, dimana inti dari hakikat nilai-nilai Islam adalah nilai yang membawa kemaslahatan dan kesejahteraan bagi seluruh makhluk (sesuai konsep rahmatan lil 'alamiin), demokratis, egalitarian, dan humanis (Haidar Putra Daulay, 2007, p. 16). Pengertian lainnya sebagaimana yang dikemukakan oleh Ratna Megawangi bahwa pendidikan karakter adalah sebuah usaha untuk mendidik anak-anak agar memiliki kecerdasan mengambil keputusan dengan bijak dan mempraktikanya dalam kehidupan sehari-hari, sehingga mereka dapat memberikan kontribusi yang positif kepada lingkungannya (Ratna Megawangi, 2010, p. 95).

Pengelolaan kegiatan santri yang menjadi basis pendidikan karakter di pesantren ini sudah menjadi budaya pesantre. Budaya identik dengan kebiasaan yang sudah biasa dilaksanakan di sebuah tempat. Hal ini sejalan dengan pendapat Verkuyl yang mengatakan bahwa kata kebudayaan itu berasal dari bahasa Sanskerta budhayah, yaitu bentuk jamak dari buddhi yang berarti roh atau akal. Perkataan kebudayaan menyatakan segala sesuatu yang diciptakan oleh budi manusia (Faisal Ismail, 1997, p. 23).

Model pendidikan karakter di atas dilaksanakan dalam sebuah proses pembentukan karakter yang dapat dilakukan dengan menekankan beberapa komponen, seperti yang dikemukakan oleh Lickona mengenai pentingnya menekankan tiga komponen karakter yang baik (Components of Good Character), yaitu; moral knowing, moral feeling, moral action (Mansur Muslich, 2011, p. 133).

Habituasi karakter kemandirian santri di Pondok Pesantren Zuhriyah dilakukan dengan menggunakan berbagai pendekatan (multi approach). Melalui pendekatan yang banyak, maka diharapkan internalisasi karakter yang dilaksanakan juga bisa mendapatkan hasil yang maksimal. Jika menganalisis pendekatan yang digunakan dalam internalisasi karakter kemandirian santri, maka pendekatan yang digunakan lebih kepada pendekatan moral action. Artinya internalisasi kemandirian santri ditanamkan dengan menggunakan media praktek dalam kehidupan sehari-hari. Pengelolaan kegiatan pesantren yang setiap hari dilaksanakan sangat efektif dalam membiasakan kemandirian dalam mengelola segala kebutuhan sosial pesantren, termasuk juga kebutuhan pribadi santri.

Selain pendekatan perkembangan moral kognitif (cognitive moral development approach), analisis nilai (value analyzis approach), klarifikasi nilai (value clarification approach), dan pembelajaran berbuat (action learning approach), Kirschenbaum juga mengungkapkan pendekatan nilai yang lain, yaitu pendekatan komprehensif. Kirschenbaum menyatakan pendekatan 
komprehensif dalam pendidikan nilai meliputi empat cara, yaitu inculcating value (inkulkasi), modelingvalue and (keteladanan), facilitating value and morality (fasilitasi nilai), skills for value development and moral literacy (pengembangan ketrampilan hidup)(Howard Kirschenbaum, 2000, pp. 31-43).

Berbagai macam teori pendekatan karakter diatas kesemuanya digunakan dalan internalisasi karakter di pesantren ini. Sebagai contohnya, pendekatan perkembangan moral kognitif (cognitive moral development approach) di pesantren ini diwujudkan dengan pengajaran kitab kuning terkait masalah akhlak yaitu kitab 'aqidatul awwam dan ta'lim muta'alim. Pendekatan analisis nilai (value analyzis approach) dan klarifikasi nilai (value clarification approach) diwujudkan dalam bentuk pemahaman santri atas hikmah pengelolaan mandiri semua kegiatan pesantren. Adapun pendekatan pembelajaran berbuat (action learning approach) diwujudkan dalam bentuk tanggung jawab santri atas terlaksananya semua kegiatan pesantren.

Kata kunci keberhasilan habituasi karakter kemandirian di Pondok Pesantren Zuhriyah terletak pada media pembiasaan yang digunakan. Guna menanamkan karakter kemandirian, pesantren ini mengandalkan media berupa pengelolaan semua kegiatan santri secara mandiri, mulai dari pengadaan konsumsi, kegiatan belajar mengajar, sampai kegiatan kemasyarakatan.

Kemandirian di pesantren ini tidak disampaikan sebatas pengetahuan dan urgensinya belaka. Jauh dari itu, pesantren ini menganggap bahwa karakter kemandirian santri menjadi karakter utama yang harus ditanamkan kepada santri dalam bentuk perilaku sehari-hari. Keberadaan semua santri yang yatim piatu mengharuskan penekanan terhadap karakter kemandirian menjadi sangat penting.

Pengelolaan kegiatan yang dilakukan secara mandiri di pesantren ini sangat berbeda jika dibandingkan dengan pengelolaan di pesantren lain. Jika di pesantren lain santri hanya bersifat membantu para ustadz atau pengelola pesantren dalam menjalankan kegiatan, maka di pesantren ini semua santri menjadi penanggung jawab utama terlaksananya kegiatan. Penanggung jawab kegiatan santri di pesantren ini menjadi tanggung jawab santri yang paling senior.

Tidak adanya intervensi pemimpin dan pengelola pesantren dalam pengelolaan kegiatan pesantren menjadikan sikap tanggung jawab santri terbentuk secara sempurna dan maksimal. Pemimpin dan pengelola pesantren hanya sebatas mengawasi semua pelaksanaan kegiatan, apabila terdapat kesulitan maka biasanya santri mendiskusikannya dengan pemimpin atau pengelola pesantren. Terlihat sekali suasana kekeluargaan yang terbentuk dalam pola komunikasi antara santri sebagai pengelola kegiatan dengan pemimpin pesantren.

Karakter kemandirian santri di pesantren ini ditanamkan menggunakan model habituasi atau pembiasaan kepada santri. Bisa disimpulkan bahwa guna menjadikan karakter kemandirian ini terpatri dalam diri santri secara kuat, maka setiap hari santri selain menempati posisi sebagai pihak yang belajar, juga berposisi sebagai pihak pengelola semua kegiatan pesantren. Dalam prakteknya, santri yang senior akan menjadi penanggung jawab kegiatan dan bertanggung jawab juga dalam membimbing santri yang masih junior dalam belajar membantu mengelola kegiatan tersebut. Model penanaman karakter seperti ini ternyata sesuai dengan konsep yang dijelaskan Novan dalam bukunya mengenai manajemen karakter. Proses tersebut digambarkan sebagai berikut: (Novan Ardy Wiyani, 2010, p. 44)

Gambar 1. Bagan Model Pembiasaan Karakter di Sekolah

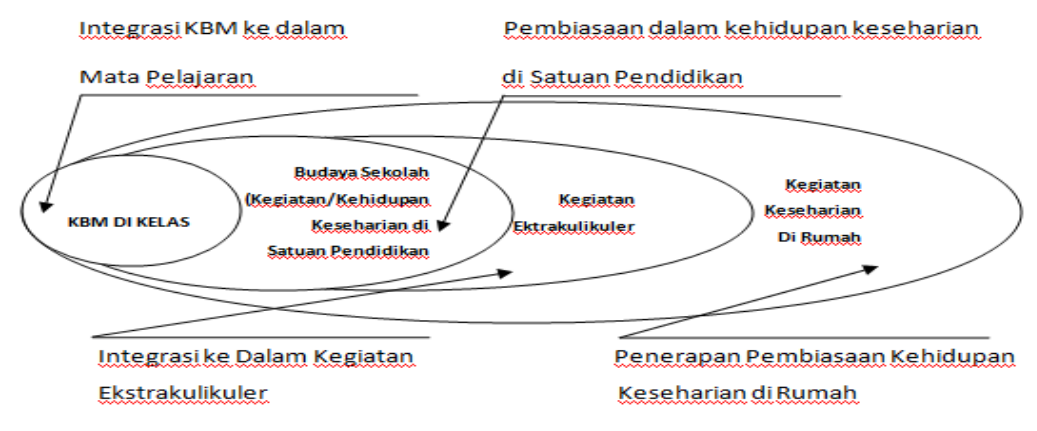

J-PAI: Jurnal Pendidikan Agama Islam

Vol. 5 No. 1 Juli-Desember 2018 
Melalui bagan diatas, Novan menjelaskan bahwa pembiasaan karakter dalam kehidupan sehari-hari dapat dilakukan dengan media berupa budaya yang terdiri dari kegiatan keseharian. Jika dihubungkan dengan model habituasi karakter kemandirian yang dilakukan di pesantren ini, maka model habituasi karakter pesantren ini Berdasarkan bagan di atas, maka dapat diketahui bahwa penanaman nilai nilai karakter harus ditumbuhkan dengan proses pembiasaan dalam keseharian (habituasi) melalui budaya sekolah (school culture) yang merupakan kunci dari keberhasilan pendidikan karakter.

Budaya sekolah yang dimaksud pada bagan diatas, jika digunakan dalam pendidikan karakter pada pesantren, maka dapat berupa budaya pesantren. Pengelolaan kegiatan yang dilakukan secara mandiri oleh santri di Pondok Pesantren Zuhriyah merupakan budaya pesantren yang sangat efektif dalam menanamkan karakter kemandirian. Budaya pesantren merupakan segala bentuk kegiatan pesantren yang sudah menjadi kebiasaan dan secara rutin dilaksanakan berdasarkan konsensus bersama warga pesantren. Proses pendidikan berbasis budaya pesantren berdasar pada metode pembiasaan atau habituasi. Artinya budaya pesantren yang merupakan hal baru bagi seorang santri yang baru masuk akan menginternalisasi seiring dengan proses waktu pembiasaan yang dilakukan.

Pendidikan karakter yang dikembangkan dalam dunia pendidikan formal bisa dikembangkan dengan tiga desain, yaitu; a) desain berbasis kelas yang berbasis pada relasi antara guru sebagai pendidik dan siswa sebagai pembelajar, b) desain berbasis kultur sekolah yang berusaha membangun kultur sekolah yang mampu membentuk karakter peserta didik dengan bantuan pranata sosial sekolah agar nilai tertentu terbentuk dan terbatinkan dalam diri peserta didik, c) desain berbasis komunitas. Hal tersebut digambarkan dalam bagan pengembangan pendidikan karakter sebagai berikut:

Gambar 2. Bagan Desain Pengembangan Pendidikan Karakter (Novan Ardy Wiyani, 2010, p. 46)

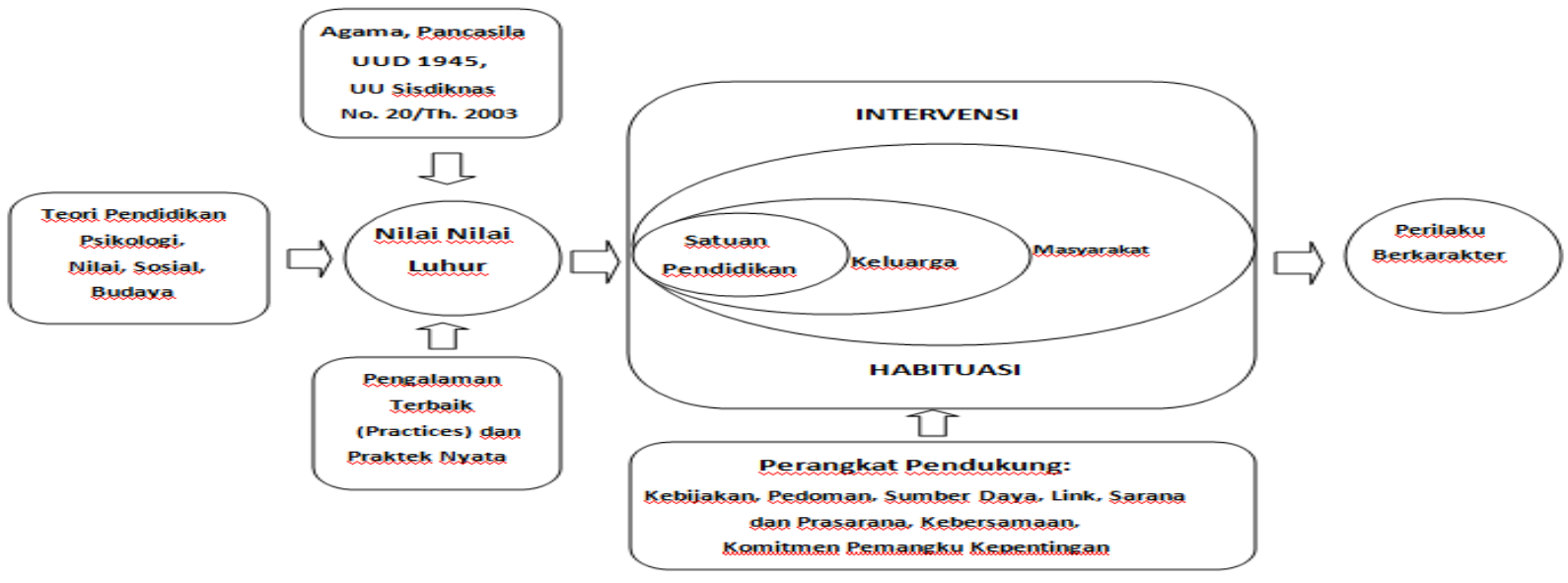

Desain berbasis kelas yang dijelaskan diatas sebenarnya juga sesuai dengan desain yang berlaku di pesantren. Hanaya saja di pesantren, desain yang berlaku adalah desain berbasis relasi antara santri dengan kyainya. Selanjutnya, desain berbasis kultur dan desain berbasis komunitas jika dilihat pelaksanaannya di pesantren ini, maka berwujud desain berbasis tradisi pesantren dan masyarakat sekitar pesantren.

Pola pengembangan pendidikan karakter di pesantren ini seudah sesuai dengan dasar teoritis pengembangan karakter jika merujuk pasa pendapat Novan diatas. Hanya saja teori pengembangan yang disampaikan diatas merupakan teori yang diaplikasikan di sekolah. Untuk itu, istilah pendidik dalam teori Novan diatas diganti dengan sosok kyai atau pemimpin pesantren dan peserta didik diganti dengan santri.

Berdasarkan bagan di atas, dapat diketahui bahwa konsep pendidikan karakter berbasis budaya pesantren merupakan salah satu desain pengembangan karakter yang ada disekolah, meskipun desain yang diterapkan di sekolah menggunakan budaya sekolah. Keberhasilan desain pendidikan karakter berbasis budaya ini tentunya tergantung pada kualitas budaya yang sudah dikembangkan di sekolah maupun di pesantren. Pesantren yang sangat mengedepankan budaya 
pesantren dalam menjaga akhlak santrinya menjadi modal yang baik untuk dijadikan sebagai sebuah desain pendidikan karakter yang ideal.

Dalam konteks pendidikan nasional, pendidikan karakter memiliki beberapa fungsi strategis, yaitu; pengembangan potensi dasar agar berhati baik, berpikiran baik, dan berperilaku baik, perbaikan perilaku yang kurang baik dan penguatan perilaku yang sudah baik, dan penyaring budaya yang kurang sesuai dengan nilai-nilai luhur Pancasila (Dharma Kesuma, dkk, 2011, p. 46).

Ketiga fungsi di atas secara esensial mengandung fungsi budaya sebagai penyaring (filter) terhadap budaya yang kurang baik. Adapun kaitannya dengan pondok pesantren, maka budaya yang sesuai atau kurang sesuai bukan didasarkan kepada komunitas sosial, akan tetapi harus didasarkan al-Qu'ran dan Hadist. Tradisi atau budaya yang kuat menjadi karakteristik sekaligus kelebihan yang dimiliki pesantren dalam melaksanakan internalisasi karakternya. Pondok Pesantren Zuhriyah sendiri dalam menanamkan karakter kemandirian memiliki ciri khas tersendiri yaitu berupa pengelolaan secara mandiri semua kegiatan pesantren oleh santri.

Karakter menjadi sebuah keniscayaan yang dapat terinternalisasi dalam diri seseorang secara baik jika ditanamkan dengan menggunakan metode pembiasaan atau habituasi. Hal ini mengingat bahwa karakter sendiri bukan sebatas pengetahuan mengenai moral belaka, tetapi menjadi sifat bahkan realisasi berupa perbuatan karakter. Dalam kamus psikologi dinyatakan bahwa karakter adalah kepribadian yang ditinjau dari titik tolak etis atau moral, misalnya kejujuran seseorang, biasanya memiliki keterkaitan dengan sifat-sifat yang relatif tetap (Hamka Abdul Azis, 2011, pp. 197-198). Dalam perspektif psikologi, karakter harus memiliki sifat yang relatif tetap.

Habituasi menjadi metode penanaman karakter di Pondok Pesantren Zuhriyah dengan menggunakan pengelolaan semua kegiatan santri secara mandiri. Karakter di Pondok Pesantren Zuhriyah menjadi sebuah ciri khas sifat dan perangai santri yang bisa dibawa sampai ke dalam kehidupan sehari-hari. Hal ini bersesuaian dengan makna karakter dalam kamus besar bahasa inggris yang menjelaskan bahwa character (karakter) adalah "The aggregate of features and traits form the individual nature of some persons or things" (The Random house Dictionary of English Language, 1983, p. 346) yang artinya keseluruhan ciri khas sifat dan perangai yang membentuk watak sekelompok orang atau barang.

Habituasi yang menjadi metode penanaman karakter santri di Pondok Pesantren Zuhriyah bertujuan agar santri mampu memiliki karakter yang dapat digunakan untuk memberikan kontribusi kepada lingkungan sekitarnya. Hal ini sebagaimana ditegaskan oleh Ratna Megawati (2010, p. 5) yang menjelaskan bahwa pendidikan karakter adalah sebuah usaha untuk mendidik anak-anak agar dapat mengambil keputusan dengan bijak dan mempraktekannya dalam kehidupan sehari-hari, sehingga mereka dapat memberikan kontribusi yang positif kepada lingkungannya

\section{KESIMPULAN}

Dunia pendidikan termasuk didalamnya pesantren sepakat bahwa karakter menjadi salah satu tujuan utama yang harus dicapai. Ada banyak model pendidikan karakter yang sudah dilaksanakan oleh lembaga pendidikan, baik lembaga formal maupun non formal. Pesantren Zuhriyah sebagai pesantren yatim piatu memiliki model penanaman karakter kemandirian yang berbeda dan diharapkan bisa juga diterapkan pada lembaga pendidikan pesantren lainnya. Jika pesantren lain dalam pengelolaan semua kegiatan santri masih dikelola oleh pimpinan atau pengurus pesantren dan santri hanya bersifat membantu pelaksanaannya, maka di pesantren ini semua kegiatan santri dikelola penuh oleh santri mulai dari pengelolaan kegiatan belajar mengajar kitab kuning, kebersihan pesantren, sampai permasalahan konsumsi pesantren.

Model pengelolaan kegiatan seperti ini menjadi praksis internalisasi karakter kemandirian santri yang sangat efektif. Kemandirian yang menjadi karakter utama yang harus dimiliki oleh semua santri yatim piatu diinternalisasikan menggunakan metode pembiasaan (habituasi). Kata kunci implementasi pembiasaan karakter pada santri terletak didalam aktifitas merencanakan, melaksanakan, mengontrol, sampai mengevaluasi kegiatan yang sudah dilaksanakan.

Guna menjadikan model internalisasi ini bisa diterapkan di pesantren lain, maka ada beberapa hal yang perlu dipersiapkan. Pemimpin atau pengelola pesantren harus membuat berbagai macam kegiatan santri. Selanjutnya, kepanitiaan semua kegiatan santri tersebut diserahkan kepada santri. Santri tidak hanya diposisikan hanya sebagai pelaksana kegiatan, akan

J-PAI: Jurnal Pendidikan Agama Islam 
tetapi juga sebagai pengelola kegiatan. Internalisasi dengan model moral action seperti yang diterapkan di pesantren ini mampu menjadi model internalisasi karakter yang menghasilkan karakter kemandirian kuat pada diri santri.

Pada ahirnya, sebagai bahan rekomendasi bagi pelaksanaan pendidikan karakter, ada satu hal penting yang layak digarisbawahi dalam pelaksanaan internalisasi karakter kemandirian di Pondok Pesantren Zuhriyah. Karakter kemandirian menjadi kebutuhan pokok bagi santri yang mayoritas berstatus yatim piatu, sehingga internalisasi nilai menjadi sangat mudah karena didukung oleh semua personil. Santri sendiri juga merasa membutuhkan karakter kemandirian karena sebuah tuntutan keadaan.

Lembaga pendidikan yang akan melaksanakan pendidikan karakter seyogyanya juga mempertimbangkan kebutuhan nilai karakter peserta didiknya, sehingga nilai yang akan ditanamkan menjadi sangat bermanfaat dan juga menjadi prioritas peserta didik. Hal ini mengingat sampai saat ini banyak pendidikan karakter yang dilaksanakan tidak mempertimbangkan kebutuhan nilai karakter bagi peserta didik.

\section{DAFTAR PUSTAKA}

Abdul Majid dan Dian Andayani. (2005). Pendidikan Agama Islam Berbasis Kompetensi (Konsep dan Implementasi Kurikulum 2004. Bandung: Remaja Rosda Karya.

Abdullah Munir. (2010). Pendidikan Karakter (Membangun Karakter Anak Sejak Dari Rumah). Yogyakarta: Pedagogia.

Darmiyati Zuchdi. (2010). Humanisasi Pendidikan (edisi ketiga). Jakarta: Bumi Aksara.

Dharma Kesuma, dkk. (2011). Pendidikan Karakter Kajian Teori dan Praktik di Sekolah. Bandung: Remaja Rosda Karya.

Doni Koesoema A. (2010). Pendidikan Karakter; Strategi Mendidik Anak di Zaman Global. Jakarta: Grasindo.

Faisal Ismail. (1997). Paradigma Kebudayaan Islam: Studi Kritis dan Refleksi Historis. Yogyakarta: Titian Ilahi Press.

Haidar Putra Daulay. (2007). Pendidikan Islam Dalam Sistem Nasional di Indonesia. Jakarta: Kencana Media.

Hamka Abdul Azis. (2011). Pendidikan Karakter Berpusat Pada Hati. Jakarta: Al-Mawardi Prima.

Howard Kirschenbaum. (2000). 100 Ways to Enchance Values and Morality. Boston: Allyyn and Bacon.

In'am Sulaiman. (2010). Masa Depan Pesantren; Eksistensi Pesantren di Tengah Gelombang Modernisme. Malang: Madani.

Kemendiknas. (2011). Pedoman Pelaksanaan Pendidikan Karakter. Jakarta: Pusat Kurikulum dan Perbukuan Kemendiknas.

Maksudin. (2009). Pendidikan Nilai Komprehensif; Teori dan Praktik. Yogyakarta: UNY Press.

Masnur Muslich. (2011). Pendidikan Karakter: Menjawab Tantangan Kritis Multidimensional, (Jakarta: Bumi Aksara, 2011), hlm. 133. Jakarta: Bumi Aksara.

Moh. Nizar. (1988). Metode Penelitian. Jakarta: Ghalia Indonesia. 
Muhammad Idrus. (2009). Metode Penelian Ilmu Sosial. Jakarta: Erlangga.

Noeng Muhadjir. (2012). Metodologi Penelitian Kualitatif. Yogyakarta: Andi Ofset.

Novan Ardy Wiyani. (2010). Manajemen Pendidikan Karakter, Konsep, dan Implementasinya di Sekolah. Yogyakarta: Pustaka Insan Madani.

Nurul Zuriah. (2011). Pendidikan Moral dan Budi Pekerti Dalam Perspektif Perubahan. Jakarta: Bumi Aksara.

Ratna Megawangi. (2010). Pendidikan Karakter; Solusi yang Tepat untuk Membangun Bangsa. Bogor: Indonesia Heritage Foundation.

Sugiyono. (2008). Metode Penelitian Pendidikan (Pendekatan Kuantitatif, Kualitatif, dan R\&D). Bandung: Alfabeta.

The Random house Dictionary of English Language. (1983). New York: Random House, Inc. 